https://doi.org/10.31426/ijamsr.2018.1.10.1018

\title{
The Relationship Between Willingness to Communicate and Writing Proficiency of Iranian EFL Learners at The Upper- Intermediate and Advanced Levels
}

\author{
Sanaz Gholami ${ }^{1}$, Reza Barzegar ${ }^{2}$ \\ English Teacher, Iran \\ University Instructor, Iran \\ Email: englishtutor2017@gmail.com
}

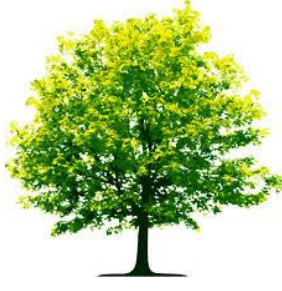

Keywords: Willingness to

Communicate, Writing

Proficiency, EFL Students,

Upper-Intermediate Level,

Advanced Level

Introduction

Communication is recognized as central to the development of human relationships (SallinenKuparinen, McCroskey, \& Richmond, 1991).

\begin{abstract}
A B S T RA C T
The present study was an attempt to investigate the relationship between willingness to communicate and writing proficiency of Iranian upper-intermediate and advanced EFL learners. To perform this, 51 male and female learners who studied at different English institutes were selected to participate in this study. At the beginning of the research, they were asked to complete the Willingness to communicate questionnaire. Having answered the questionnaire, the participants were supposed to write a paragraph to show their writing ability. At last, in order to explore the relationship between WTC and writing ability of the EFL learners, a series of Pearson product-moment correlations were run. The results revealed that there was significant correlation between willingness to communicate and writing proficiency of upper-intermediate and advanced EFL learners.
\end{abstract}

Citation: Sanaz Gholami, Reza Barzegar (2018). The Relationship Between Willingness to Communicate and Writing Proficiency of Iranian EFL Learners at The Upper- Intermediate and Advanced Levels. International Journal of Advanced Multidisciplinary Scientific Research (IJAMSR) ISSN:2581-4281 Vol 1, Issue 10, December, 2018, \#Art.1018, pp 69-81 


\section{International Journal of Advanced Multidisciplinary Scientific Research (IJAMSR) ISSN:2581-4281}

people, gradually acquires the language. In this regard, willingness to communicate, defined as a stable predisposition toward communication when free to choose to do so (McCroskey\& Baer, 1985), is the most basic orientation towards communication.

\subsection{WTC}

The WTC concept was first developed in the first language communication by McCroskey and Richmond (1990). They defined it as the individual's intention to initiate communication and participate in conversation in varioussituations. MacIntyre, Baker, Clement and Donovan (2003) define willingness to communicate as "the predisposition toward or away from communicating, given the choice" (p.538). Willingness to communicate which is defined as the final intention to initiate a communication plays an important role in language learning. The importance of willingness to communicate arises from the role of interaction in language development (Molberg, 2010). According to Kang (2005), more interaction causes more language development and learning. Willingness to communicate affects not only speaking but also listening, writing, and reading modes (McIntyre et al., 1998). As such, L2 researchers argue that willingness to communicate in L2 is one of the best predictors of success in L2 acquisition. Therefore, L2 students with high levels of willingness to communicate may have the greater possibility to develop L2 proficiency (Kim, 2004). The process of learning is primarily based on the main skills of a language (i.e. speaking, listening, reading and writing) and sub-skills (i.e. vocabulary, pronunciation and grammar). Learning language skills and sub-skills have important roles in students' communication in the real world (Brown, 2007).

\subsection{Writing}

Among the skills, writing is considered as a vital skill in the process of language learning. It is obvious that for students, writing is a means of recording and reformulating knowledge and developing ideas. It may also be a means of personal discovery, of creating, and of self-expression. According to Richards and Schmidt (2010), "writing is viewed as the result of complex processes of planning, drafting, reviewing and revising and some approaches to the teaching of first and second language writing teach students to use these processes " (p. 641). Writing is claimed to play an important role in one's intellectual development and career preparation (Gere, 1985). Öz (2006) states that "writing is the written expression of thoughts, desires, emotions, and schemes; this requires skill rather than knowledge" (p. 251). So to speak, writing is a skill that serves individuals' communication needs as well as their learning. As writing skills of students develop, they begin to apply their knowledge to the written expression more and more easily and go beyond what they have learnt (Raimes, 1983). According to Dyson (1995), writing is not merely an individual activity but a process which requires social interaction.

Writing has long been a problem among the four language skills for language leraners. According to Luchini (2010), the writing skill is a challenging task because it necessitates a wide range of cognitive, interpersonal, and linguistic strategies of which EFL students are mostly unaware. Langan (2005) states that writing is a very complex skill including different stages 


\section{International Journal of Advanced Multidisciplinary Scientific Research (IJAMSR) ISSN:2581-4281}

and sub- processes including discovering and developing a thesis, organizing, revising, and editing what is written to have an effective, error-free piece of writing. Similarly, EFL/ESL writing is regarded as a difficult, complex and challenging process (Alsamadani, 2010). Wade (1995) persuasively states that writing is an essential ingredient in critical thinking instruction, since it promotes greater self-reflection and the taking of broader perspectives than does oral expression. Suitable written assignments, she believes, can stimulate classroom writers to enhance their active learning spontaneously. Writing, especially the process approach, is, by nature, a self-critical one. It lends itself to the kind of introspection that would prompt learners to reflect on thei understanding, and to communicate their feelings about what they know, what they are doing, what they are struggling with, and how they are experiencing their learning (White \& McGovern,1994).

\section{RelatedStudies}

Researchers in WTC seem to agree that learners who actively use the language and have high WTC have a greater potential to develop language proficiency such as writing; since they have more opportunities to communicate with others. Thus, the more willing to communicate language learners are, the more likely they are to attain greater language proficiency (McIntyre, 1994; McIntyre et al., 1998; Yashima, 2002). Mastering writing is the most difficult for first and foreign language learners. It is a complicated process since it involves a series of forward and backward movements between the writer's ideas and the written text (Harris \&
Cunningham, 1994), and requires a high level of language control and good WTC (Murcia \&Olshtain,2000).

Willingness to communicate is emerging as a concept to account for individuals' first language and second language communication. Willingness to communicate is defined as a learner's readiness to enter into discourse at a particular time with a specific person or persons, using a L2. Learners need to be not only able to communicate but also willing to communicate in the L2 (Bergil, 2016). Based on the importance of willingness to communicate in L2 learning, several research studies on investigating the relationship between willingness to communicate and different aspects of second/foreign language learning are sketched outbelow.

Among the research studies, MoradiKhazaei, MoinZadeh and Ketabi (2012) investigated the effect of class size on the Iranian EFL students' willingness to communicate among three different class sizes. The participants were 30 male and female adult Iranian intermediate EFL learners. All of them were attending the same institute in Kermanshah, Iran. The participants were selected from three separate classes: one class (class A) containing five students which was regarded as a small class in this institute, and the other class (class B) consisted of ten students, and there were fifteen students in class C. The data were collected in fall 2012. Three classes with varying sizes were used for data collection procedure. The researcher observed all three classes to record the amount of time each student talked and participated in activities. Furthermore, the number of talk turns during communication and conversation for each student was calculated. The study employed a one way ANOVA to investigate the effect of class size on students' willingness to communicate. The results 


\section{International Journal of Advanced Multidisciplinary Scientific Research (IJAMSR) ISSN:2581-4281}

revealed how strongly class size can affect the participation of learners in class discussions and WTC. Teachers in larger classes should be aware to employ more communicative strategies in order to encourage the students to participate and to be involved in classinteraction.

In another research, Valadi, Rezaee, and KoganiBaharvand (2015) investigated whether WTC and language learners' oral proficiency were related in an Iranian context. Participants of the study were selected randomly from two branches of Iran Language Institute, Khoramabad, Iran. Given the noncoeducational policy of the institute, they had two gender-based

groups:

femalegroup $(n=70)$ andmalegroup $(n=70)$. Basedontheinsti tutes

placement criteria, they were intermediate students and their age ranged from 15 to 30 years old. In order to measure the learners' WTC levels, a modified version of the Likert-type questionnaire developed by MacIntyre et al. (2001) and Baghai and Dourakhshan (2011) was distributed among the participants. Furthermore, a few context-bound adaptations were made to the items. The questionnaire included 25 items relevant to the factors contributing to WTC in learning a second language. The questionnaire items were translated into participants' native language to avoid any possible misunderstandings. To ensure parallelism with the English versions of the questionnaires, the questionnaire items were translated by one of the researchers in this study and subsequently verified by a professional translator. The questionnaire followed a Likert type scale and the learners were asked to indicate their responses to the items across the continuum. Along with the questionnaire, short interviews were held with some of the participants randomly to approve their responses. In addition, in order to measure students' speaking ability, along with administration of the institute tests, the teachers' judgment of the language learners was used to confirm the obtained results. The speaking test was administered at the end of the course to estimate the speaking ability scores. Pearson correlation clarified the degree of correlation between WTC level and speaking proficiency. To find out whether there was a significant difference between the two groups in terms of their levels of WTC, an independent-samples t-test was run. According to the findings of the study, there was a strong correlation between the participants' WTC level and their oral proficiency. That is, those having a high level of WTC to open up a conversation are more competent in speaking ability in theclassroom.

Similarly, Baghaei and Dourakhshan (2012) attempted to explore the possible relationship between WTC and its components and success in foreign language learning. To perform this, a sample of 148 undergraduate English learners were selected. The Willingness to Communicate in a Foreign Language Scale (WTC-FLS) developed by Baghaei (2011) was given to the participants along with a C-Test battery. WTC-FLS is a questionnaire with 20 statements about respondents' readiness to initiate communication under different circumstances, different contexts and with different people. Respondents endorse their levels of agreeability with the statements on a 2 point agree/disagree scale. "Agrees" are scored 1 and “disagrees" are scored 0. The WTC-FLS is written to measure WTC in English as a foreign language. However, it can easily be adapted to be used for other 


\section{International Journal of Advanced Multidisciplinary Scientific Research (IJAMSR) ISSN:2581-4281}

languages. Results show that two out of the three subscales of WTC, namely, willingness to communicate in the school context and willingness to communicate with native speakers of English, were moderately correlated with success in learning English as foreign language as measured by $\mathrm{C}$-Test. The other subscale of WTC, i.e., willingness to communicate with nonnative speakers of English was not correlated with success in foreign languagelearning.

Tousi and Khalaji (2014) were other researchers who attempted to explore Iranian EFL learners' degree of willingness to communicate in English. The sample were only male students aged 16 to 22 , and with various motivations and goals in learning English, and the data were collected from the language institute the researcher had easy access to. Also the subjects, 60 EFL learners, were divided into two groups, one control group, and the other experimental group, each consisting of 30 students. The research errandomly selected four intact classes to take part in the questionnaire survey.

The participants had studied English for 2 years; they were at pre-intermediate level. For the qualitative part of this study, which could reveal the selected students' actual WTC behavior, thirty students were selected to hold talking sessions with. The other 30 students formed the control group. Interview data were analyzed quantitatively by ANCOVA in order to find the relationship between the students' level of WTC and speaking test. It was found out at both tests that talking sessions were effective and experimental group outperformed the control group. Based on the statistical procedures on the gathered data, we were on the safe grounds to claim that there was a statistically significant relationship between Iranian students' WTC and their degree of learning English.

More recently, Bergil (2016) aimed to investigate the Turkish preparatory class students' WTC levels and the effects of individual differences on their WTC levels. 73 students, who were studying English as a foreign language (EFL) in the preparatory class in the foreign language department in Amasya University, served as the participants of the study. In this study, two different data collection instruments were conducted to different participants. At first, the scale prepared by McCroskey (1992) was utilized to measure the students' WTC and some demographic information of students were gathered to make contributions to the relationship between their WTC and the other demographic variables such as proficiency level, length of studying, being abroad, communicating with foreigners, and being introvert or extrovert. After that, a 5 point Likert-type scale consonant to the WTC was adapted by the researcher for the purpose of getting the instructors' points of view about the overall speaking skills of the participants. The options of the scale ranged from " $1=$ weak', “2=adequate”, “' $3=$ good”, “4=excellent'” and ' $5=$ No idea and was filled by the speaking course instructors who were native speaker Fulbright assistants. The 5 point Likert-type scale was filled by these instructors for each preparatory class student to unveil their overall speaking skills in terms of receiver and context-type willingness to communicate sub-scores. In the statistical procedure, a series of independent samples t-tests and one-way ANOVAs were applied to provide the answers to the related research questions. The results showed that preparatory class students have mostly weak and adequate overall speaking skills which can be related with the activities the instructors and the 
curriculum include for the course content or the ability of instructors' materialadaptation.

\section{Rationale of the study}

The above-mentioned researches investigated the relationship between willingness to communicate and different aspects of foreign language learning. However, to the best of researchers' knowledge, few research studies have attempted to investigate the relationship between willingness to communicate and writing ability of foreign language learners. This brings us to the rationale of the present study: to bridge the gap in this area and tap into any possible relationships between WTC and the writing performance of EFL learners.

\section{Method}

\subsection{Participants}

The total number of population of the present study was 51 male and female learners who studied at different English institutes. The learners varied in age from 19 to 29 years old and they had the same native language which was Persian. The participants of this study studied English as a foreign language for 2.5 to 3 years in private language institutes such as Safir, Kaj, Shokouh and Iran.

\subsection{Instrumentation}

In the present study, the WTC questionnaire was utilized to investigate the relationship between willingness to communicate and writing proficiency of Iranian upperintermediate and advanced EFL learners. The instrument that was used for this research is a modified version of the likert-type questionnaire developed by MacIntyre et al. (2001). The questionnaire consisted of one part (Appendix A) to measure their willingness to communicate inside the class. In order to obtain the objectives of the study, the participants were assured that the information provided by them in the questionnaire would be confidential and used only for scientificpurposes.

\subsection{Procedure}

In order to conduct the research study and to test the research hypotheses, the following steps were taken:

Step 1: Administrating the Willingness to Communicate Questionnaire

The participants were required to fill the questionnaire in accordance with the extent to which they agreed with the questionnaire statements. In order to do this, a Likert scale (rating scale or the Likert-type scale) was used. The WTCquestionnaire consisted of one main section: It comprised of 27 items which range from 1 to 5 ( 1 = almost never willing, $2=$ sometimes willing, $3=$ willing half of the time, $4=$ usually willing and $5=$ almost always willing). Learners were asked to indicate how willing they would be to communicate inside the class. The highest degree of willingness would receive 5 points, and the lowest 1 point. The participants were asked to fill the total questionnaire carefully within maximum 10 minutes; then the outliers would be excluded from the collected data, and finally the quantitative analysis would be carried out with the help of SPSS in order to decide whether there is any statistically significant relationship between willingness to communicate and writing proficiency. Another activity was writing task shown in AppendixB. 


\section{International Journal of Advanced Multidisciplinary Scientific Research (IJAMSR) ISSN:2581-4281}

\section{Step 2: Administration of Paragraph Writing}

Having administrated the mentioned questionnaire, the whole population of the present study was supposed to write a paragraph to show their writing ability. Each candidate had 30 minutes to write a paragraph in accordance with the suggested topic by the researcher. In order to write a good paragraph, the researchers presented a step by step guide to their students: deciding the topic of paragraph, developing a topic sentence, demonstrating their point, giving meaning to the paragraph, concluding, and finally proofreading.

\section{Results}

\subsection{Descriptive Statistics}

Before any inferential on the different test scores, it is necessary to see some basic descriptive statistics of the scores depicted in the following table.

Table 5.1

Descriptive Statistics

\begin{tabular}{|c|c|c|c|c|c|c|c|c|c|c|c|c|c|}
\hline & $\mathrm{N}$ & $\begin{array}{l}R \\
\text { an } \\
\text { ge }\end{array}$ & $\begin{array}{c}\text { Mini } \\
\mathrm{mu} \\
\mathrm{m}\end{array}$ & $\begin{array}{c}\text { Maxi } \\
\mathrm{mu} \\
\mathrm{m}\end{array}$ & $\mathrm{S}$ & & $\begin{array}{l}M \\
e \\
a \\
n\end{array}$ & & $\begin{array}{c}\text { Vari } \\
\text { anc } \\
\text { e }\end{array}$ & & $\begin{array}{l}\text { Sk } \\
\text { ew } \\
\text { ne } \\
\text { ss }\end{array}$ & & $\begin{array}{l}\mathrm{K} \\
\mathrm{u} \\
\mathrm{r} \\
\mathrm{t} \\
\mathrm{O} \\
\mathrm{S} \\
\mathrm{i} \\
\mathrm{s}\end{array}$ \\
\hline & $\begin{array}{l}\text { Sta } \\
\text { tisti } \\
\text { C }\end{array}$ & $\begin{array}{r}\text { Sta } \\
\text { tisti } \\
\text { C }\end{array}$ & $\begin{array}{r}\text { Sta } \\
\text { tisti } \\
\text { C }\end{array}$ & $\begin{array}{r}\text { Sta } \\
\text { tisti } \\
\text { C }\end{array}$ & $\begin{array}{r}\text { Sta } \\
\text { tisti } \\
\text { C }\end{array}$ & $\begin{array}{l}\text { Stat } \\
\text { istic }\end{array}$ & $\begin{array}{l}\text { Std. } \\
\text { Erro } \\
r\end{array}$ & $\begin{array}{r}\text { Sta } \\
\text { tisti } \\
\text { C }\end{array}$ & $\begin{array}{r}\text { Sta } \\
\text { tisti } \\
\text { C }\end{array}$ & $\begin{array}{c}\text { Sta } \\
\text { tisti } \\
\text { C }\end{array}$ & $\begin{array}{l}\text { Std } \\
\text { Err } \\
\text { or } \\
\end{array}$ & \begin{tabular}{|l} 
Stat \\
istic
\end{tabular} & $\begin{array}{c}\text { Std. } \\
\text { Error }\end{array}$ \\
\hline $\begin{array}{l}\text { WTSRa } \\
\text { ter1 }\end{array}$ & 51 & $\begin{array}{r}40 . \\
00\end{array}$ & $\begin{array}{l}10 . \\
00\end{array}$ & $\begin{array}{c}50 . \\
00\end{array}$ & $\begin{array}{r}158 \\
0.0 \\
0 \\
\end{array}$ & $\begin{array}{r}30.9 \\
804\end{array}$ & $\begin{array}{c}1.1 \\
325 \\
8 \\
\end{array}$ & $\begin{array}{l}8.08 \\
824\end{array}$ & $\begin{array}{r}65.4 \\
20\end{array}$ & $\begin{array}{r}.36 \\
0 \\
\end{array}$ & $\begin{array}{r}.33 \\
3\end{array}$ & $\begin{array}{r}1.46 \\
8\end{array}$ & .656 \\
\hline $\begin{array}{l}\text { WTSRa } \\
\text { ter2 }\end{array}$ & 51 & $\begin{array}{r}40 . \\
00\end{array}$ & $\begin{array}{r}10 . \\
00\end{array}$ & $\begin{array}{r}50 . \\
00\end{array}$ & $\begin{array}{r}148 \\
6.0 \\
0 \\
\end{array}$ & $\begin{array}{r}29.1 \\
373\end{array}$ & $\begin{array}{c}1.1 \\
212 \\
8 \\
\end{array}$ & $\begin{array}{l}8.00 \\
755\end{array}$ & $\begin{array}{r}64.1 \\
21\end{array}$ & $\begin{array}{r}.11 \\
1\end{array}$ & $\begin{array}{r}.33 \\
3\end{array}$ & $\begin{array}{r}1.85 \\
1\end{array}$ & .656 \\
\hline $\begin{array}{l}\text { WTSAv } \\
\text { erage }\end{array}$ & 51 & $\begin{array}{r}40 . \\
00\end{array}$ & $\begin{array}{l}10 . \\
00\end{array}$ & $\begin{array}{r}50 . \\
00\end{array}$ & $\begin{array}{r}153 \\
3.0 \\
0 \\
\end{array}$ & \begin{tabular}{|r|}
30.0 \\
588
\end{tabular} & $\begin{array}{c}1.1 \\
080 \\
5 \\
\end{array}$ & $\begin{array}{l}7.91 \\
306\end{array}$ & $\begin{array}{r}62.6 \\
16\end{array}$ & $\begin{array}{r}.09 \\
4 \\
\end{array}$ & $\begin{array}{r}.33 \\
3\end{array}$ & $\begin{array}{r}1.81 \\
8\end{array}$ & .656 \\
\hline $\begin{array}{l}\text { Item } 1 \mathrm{~A} \\
\text { verage }\end{array}$ & 51 & $\begin{array}{r}4.0 \\
0\end{array}$ & $\begin{array}{r}1.0 \\
0\end{array}$ & $\begin{array}{r}5.0 \\
0\end{array}$ & $\begin{array}{r}164 . \\
00\end{array}$ & $\begin{array}{r}3.21 \\
57\end{array}$ & $\begin{array}{l}.1 \\
2 \\
5 \\
4 \\
4 \\
\end{array}$ & $\begin{array}{r}.895 \\
85\end{array}$ & .803 & $\begin{array}{r}- \\
.77 \\
4\end{array}$ & $\begin{array}{r}.33 \\
3\end{array}$ & .536 & .656 \\
\hline $\begin{array}{l}\text { Item2A } \\
\text { verage }\end{array}$ & 51 & $\begin{array}{r}4.0 \\
0\end{array}$ & $\begin{array}{r}1.0 \\
0\end{array}$ & $\begin{array}{r}5.0 \\
0\end{array}$ & $\begin{array}{r}156 . \\
00\end{array}$ & $\begin{array}{r}3.05 \\
88\end{array}$ & $\begin{array}{l}.1 \\
1 \\
7 \\
7 \\
0 \\
\end{array}$ & $\begin{array}{r}.840 \\
52\end{array}$ & .706 & $\begin{array}{r}. \\
04 \\
0\end{array}$ & $\begin{array}{r}.33 \\
3\end{array}$ & .796 & .656 \\
\hline $\begin{array}{l}\text { Item3A } \\
\text { verage }\end{array}$ & 51 & $\begin{array}{r}4.0 \\
0\end{array}$ & $\begin{array}{r}1.0 \\
0\end{array}$ & $\begin{array}{r}5.0 \\
0\end{array}$ & $\begin{array}{r}147 . \\
50\end{array}$ & $\begin{array}{r}2.89 \\
22\end{array}$ & $\begin{array}{l}.1 \\
0 \\
8 \\
\end{array}$ & $\begin{array}{r}.776 \\
62\end{array}$ & .603 & $\begin{array}{r}- \\
.45 \\
8 \\
\end{array}$ & $\begin{array}{r}.33 \\
3\end{array}$ & $\begin{array}{r}1.39 \\
1\end{array}$ & .656 \\
\hline
\end{tabular}

\begin{tabular}{|c|c|c|c|c|c|c|c|c|c|c|c|c|c|}
\hline & & & & & & & $\begin{array}{l}7 \\
5\end{array}$ & & & & & & \\
\hline $\begin{array}{l}\text { Item4A } \\
\text { verage }\end{array}$ & 51 & $\begin{array}{r}4.0 \\
0\end{array}$ & $\begin{array}{r}1.0 \\
0\end{array}$ & $\begin{array}{r}5.0 \\
0\end{array}$ & $\begin{array}{r}147 . \\
00\end{array}$ & $\begin{array}{r}2.88 \\
24\end{array}$ & $\begin{array}{l}.1 \\
0 \\
9 \\
8 \\
9\end{array}$ & $\begin{array}{r}.784 \\
78\end{array}$ & 616 & $\begin{array}{r}.36 \\
8\end{array}$ & $\begin{array}{r}.33 \\
3\end{array}$ & $\begin{array}{r}1.25 \\
7\end{array}$ & .656 \\
\hline $\begin{array}{l}\text { Item5A } \\
\text { verage }\end{array}$ & 51 & $\begin{array}{r}3.0 \\
0\end{array}$ & $\begin{array}{r}1.0 \\
0\end{array}$ & $\begin{array}{r}4.0 \\
0\end{array}$ & $\begin{array}{r}137 . \\
00\end{array}$ & $\begin{array}{r}2.68 \\
63\end{array}$ & $\begin{array}{l}.0 \\
9 \\
9 \\
9 \\
6\end{array}$ & $\begin{array}{r}.713 \\
87\end{array}$ & .510 & $\begin{array}{r}.22 \\
6\end{array}$ & $\begin{array}{r}.33 \\
3\end{array}$ & .774 & .656 \\
\hline $\begin{array}{l}\text { Item6A } \\
\text { verage }\end{array}$ & 51 & $\begin{array}{r}3.0 \\
0\end{array}$ & $\begin{array}{r}1.0 \\
0\end{array}$ & $\begin{array}{r}4.0 \\
0\end{array}$ & $\begin{array}{r}139 . \\
50\end{array}$ & $\begin{array}{r}2.73 \\
53\end{array}$ & $\begin{array}{l}1 \\
0 \\
0 \\
3 \\
5\end{array}$ & $\begin{array}{r}.716 \\
61\end{array}$ & .514 & $\begin{array}{r}. \\
.42 \\
6\end{array}$ & $\begin{array}{r}.33 \\
3\end{array}$ & .812 & .656 \\
\hline $\begin{array}{l}\text { Item7A } \\
\text { verage }\end{array}$ & 51 & $\begin{array}{r}3.0 \\
0\end{array}$ & $\begin{array}{r}1.0 \\
0\end{array}$ & $\begin{array}{r}4.0 \\
0\end{array}$ & $\begin{array}{r}134 . \\
50\end{array}$ & $\begin{array}{r}2.63 \\
73\end{array}$ & $\begin{array}{l}.1 \\
0 \\
0 \\
0 \\
8\end{array}$ & $\begin{array}{r}.714 \\
69\end{array}$ & .511 & $\begin{array}{r}.00 \\
6\end{array}$ & $\begin{array}{r}.33 \\
3\end{array}$ & .758 & .656 \\
\hline \begin{tabular}{l|} 
Item $8 \mathrm{~A}$ \\
verage
\end{tabular} & 51 & $\begin{array}{r}3.0 \\
0\end{array}$ & $\begin{array}{r}1.0 \\
0\end{array}$ & $\begin{array}{r}4.0 \\
0\end{array}$ & $\begin{array}{r}135 . \\
00\end{array}$ & $\begin{array}{r}2.64 \\
71\end{array}$ & $\begin{array}{l}.1 \\
0 \\
2 \\
2 \\
2\end{array}$ & $\begin{array}{r}.730 \\
03\end{array}$ & .533 & $\begin{array}{r}.02 \\
4\end{array}$ & $\begin{array}{r}.33 \\
3\end{array}$ & .518 & .656 \\
\hline $\begin{array}{l}\text { Item9A } \\
\text { verage }\end{array}$ & 51 & $\begin{array}{r}4.0 \\
0\end{array}$ & $\begin{array}{r}1.0 \\
0\end{array}$ & $\begin{array}{r}5.0 \\
0\end{array}$ & $\begin{array}{r}161 . \\
00\end{array}$ & $\begin{array}{r}3.15 \\
69\end{array}$ & $\begin{array}{l}.1 \\
2 \\
3 \\
2 \\
6\end{array}$ & $\begin{array}{r}.880 \\
29\end{array}$ & .775 & $\begin{array}{r}- \\
.75 \\
3\end{array}$ & $\begin{array}{r}.33 \\
3\end{array}$ & .623 & .656 \\
\hline $\begin{array}{l}\text { Item } 10 \\
\text { Averag } \\
\mathrm{e}\end{array}$ & 51 & $\begin{array}{r}4.0 \\
0\end{array}$ & $\begin{array}{r}1.0 \\
0\end{array}$ & $\begin{array}{r}5.0 \\
0\end{array}$ & $\begin{array}{r}195 . \\
50\end{array}$ & $\begin{array}{r}3.83 \\
33\end{array}$ & $\begin{array}{l}.1 \\
2 \\
7 \\
3 \\
2\end{array}$ & $\begin{array}{r}.909 \\
21\end{array}$ & .827 & $\begin{array}{r}- \\
.76 \\
8\end{array}$ & $\begin{array}{r}.33 \\
3\end{array}$ & .681 & .656 \\
\hline $\begin{array}{l}\text { WTC1t } \\
08\end{array}$ & 51 & $\begin{array}{r}26 . \\
00\end{array}$ & $\begin{array}{l}10 . \\
00\end{array}$ & $\begin{array}{r}36 . \\
00\end{array}$ & $\begin{array}{r}131 \\
3.0 \\
0\end{array}$ & $\begin{array}{r}25.7 \\
451\end{array}$ & $\begin{array}{l}.8 \\
1 \\
6 \\
4 \\
2\end{array}$ & $\begin{array}{l}5.83 \\
041\end{array}$ & $\begin{array}{r}33.9 \\
94\end{array}$ & $\begin{array}{r}.38 \\
4\end{array}$ & $\begin{array}{r}.33 \\
3\end{array}$ & .130 & .656 \\
\hline $\begin{array}{l}\text { WTC9t } \\
014\end{array}$ & 51 & $\begin{array}{r}22 . \\
00\end{array}$ & $\begin{array}{r}8.0 \\
0\end{array}$ & $\begin{array}{l}30 . \\
00\end{array}$ & $\begin{array}{r}998 . \\
00\end{array}$ & $\begin{array}{r}19.5 \\
686\end{array}$ & $\begin{array}{l}.7 \\
0 \\
2 \\
5 \\
2\end{array}$ & $\begin{array}{l}5.01 \\
699\end{array}$ & $\begin{array}{r}25.1 \\
70\end{array}$ & $\begin{array}{r}.07 \\
6\end{array}$ & $\begin{array}{r}.33 \\
3\end{array}$ & -.180 & .656 \\
\hline $\begin{array}{l}\text { WTC15 } \\
\text { to22 }\end{array}$ & 51 & $\begin{array}{r}24 . \\
00\end{array}$ & $\begin{array}{r}11 . \\
00\end{array}$ & $\begin{array}{r}35 . \\
00\end{array}$ & $\begin{array}{r}121 \\
0.0 \\
0\end{array}$ & $\begin{array}{r}23.7 \\
255\end{array}$ & $\begin{array}{c}1.0 \\
109 \\
5 \\
\end{array}$ & $\begin{array}{l}7.21 \\
964\end{array}$ & $\begin{array}{r}52.1 \\
23\end{array}$ & $\begin{array}{r}.19 \\
4 \\
\end{array}$ & $\begin{array}{r}.33 \\
3\end{array}$ & $\begin{array}{r}1.17 \\
4 \\
\end{array}$ & .656 \\
\hline $\begin{array}{l}\text { WTC23 } \\
\text { to27 }\end{array}$ & 51 & $\begin{array}{l}17 . \\
00\end{array}$ & $\begin{array}{r}8.0 \\
0\end{array}$ & $\begin{array}{r}25 . \\
00\end{array}$ & $\begin{array}{r}898 . \\
00\end{array}$ & $\begin{array}{r}17.6 \\
078\end{array}$ & $\begin{array}{l}.5 \\
6 \\
9 \\
8 \\
8 \\
\end{array}$ & $\begin{array}{l}4.06 \\
978\end{array}$ & $\begin{array}{r}16.5 \\
63\end{array}$ & $\begin{array}{r}.41 \\
2\end{array}$ & $\begin{array}{r}.33 \\
3\end{array}$ & -.433 & .656 \\
\hline $\begin{array}{l}\text { WTCTo } \\
\text { tal }\end{array}$ & 51 & $\begin{array}{r}78 . \\
00\end{array}$ & $\begin{array}{r}45 . \\
00\end{array}$ & $\begin{array}{r}123 . \\
00\end{array}$ & $\begin{array}{r}441 \\
9.0 \\
0 \\
\end{array}$ & $\begin{array}{r}86.6 \\
471\end{array}$ & $\begin{array}{c}2.5 \\
492 \\
5 \\
\end{array}$ & $\begin{array}{r}18.2 \\
053 \\
0 \\
\end{array}$ & $\begin{array}{l}331 . \\
433\end{array}$ & $\begin{array}{r}.23 \\
4 \\
\end{array}$ & $\begin{array}{r}.33 \\
3\end{array}$ & -.438 & .656 \\
\hline \begin{tabular}{l|}
$\begin{array}{l}\text { Valid N } \\
\text { (listwis } \\
\text { e) }\end{array}$ \\
\end{tabular} & 51 & & & & & & & & & & & & \\
\hline
\end{tabular}

\subsection{Reliability Statistics}

For the WTC questionnaire, we could compute the Cronbach's alpha which is formally used as a (n) (lower bound) estimate of the reliability of a questionnaire. The following table provides its value for the mentioned test questions. 
https://doi.org/10.31426/ijamsr.2018.1.10.1018

I J A M S R

\section{International Journal of}

Advanced Multidisciplinary Scientific Research (IJAMSR) ISSN:2581-4281

Cronbach's Alpha

\section{.817}

5

The Cronbach's Alpha showed an acceptable range of reliability (i.e., 0.817).

\subsection{Inferential Statistics}

First, let us study the Correlations between WTS scores based on the ratings of the two raters displayed in Table5.3.

\section{Table 5.3}

Correlations between WTS scores based on the two raters

\begin{tabular}{|l|r|r|}
\hline & WTSRater1 & WTSRater2 \\
\hline WTSRater1 & 1 & $.934^{* *}$ \\
PearsonCorrelation & 51 & .000 \\
Sig. (2- & & 51 \\
tailed) N & & \\
\hline WTSRater2 & $.934^{* * *}$ & 1 \\
PearsonCorrelation & .000 & 51 \\
Sig. (2- & 51 & \\
tailed) N & & \\
\hline
\end{tabular}

**. Correlation is significant at the 0.01 level (2-tailed).

As shown, the significance level was 0.000 and it was less than error value $0.05(\mathrm{p}<0.05)$. Moreover, the Correlation Coefficient (r) was equal to 0.934 that indicated a significant correlation between willingness to communicate and writing proficiency of upperintermediate EFL learners.
Table 5.4

Correlations between WTS Average \& WTC Scores

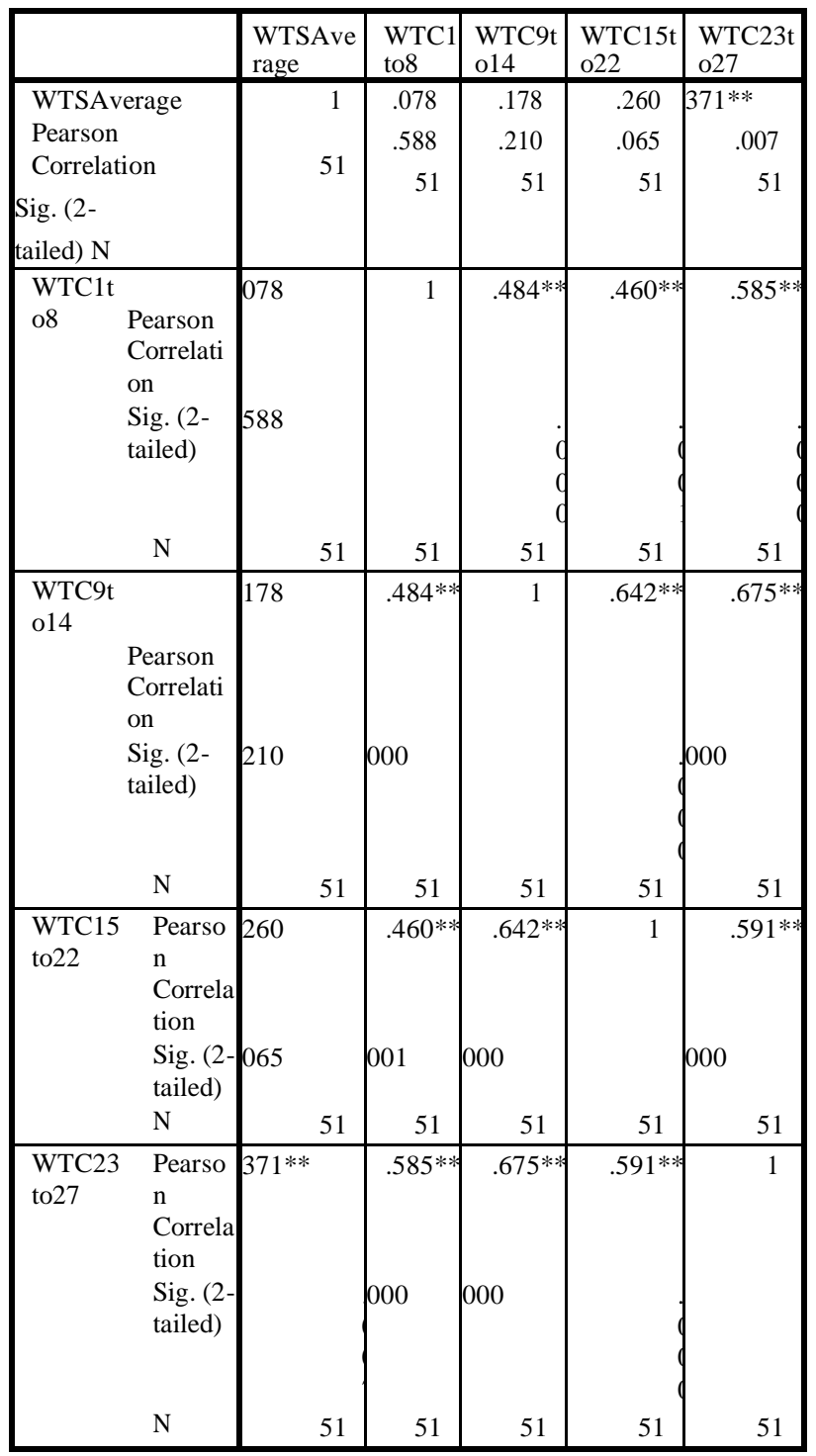

**. Correlation is significant at the 0.01 level (2-tailed).

Table 5.4 calculated correlations among speaking, reading, writing, comprehension inside the class by running Pearson correlation. Based on the obtained results from table 5.5, there were correlations among speaking, reading, writing, comprehension inside the class. 
https://doi.org/10.31426/ijamsr.2018.1.10.1018

I J A M S R

\section{International Journal of} Advanced Multidisciplinary Scientific Research (IJAMSR) ISSN:2581-4281

Table 5.5

Correlations between WTC scores based on the two raters

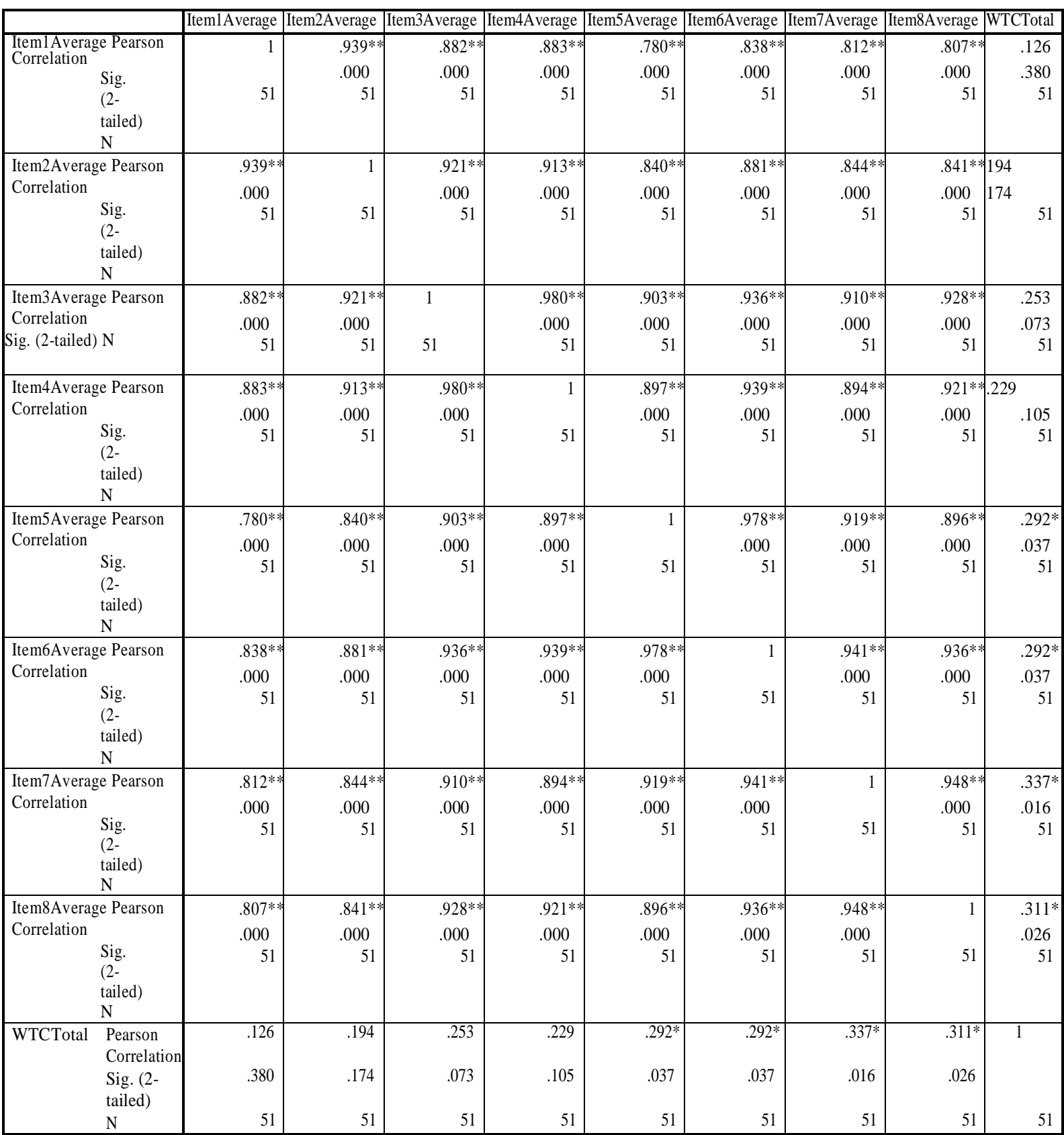

**. Correlation is significant at the 0.01 level (2-tailed).

*. Correlation is significant at the 0.05 level (2-tailed). 


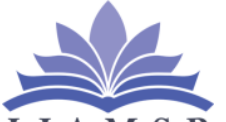

I J A M S R

International Journal of Advanced Multidisciplinary Scientific Research (IJAMSR) ISSN:2581-4281

Table 5.5 calculated correlations among items 1 to 8 by running Pearson correlation. The Obtained results revealed that there were correlations among items 1 to 8 of the willingness to communicate questionnaire.

Based on above explanations and obtained results from table 4.11, it was found that there was significant correlation between willingness to communicate and writing proficiency of upper-intermediate and advanced EFL learners.

\section{Discussion}

The obtained results from the present study revealed that there was significant correlation between willingness to communicate and writing proficiency of upperintermediate EFL learners.

Considering the results obtained from the analysis of the related data, it can be argued that the correlation between willingness to communicate and writing proficiency of upper-intermediate and advanced EFL learners was established. To the researcher, the connection between the main language skill (writing) and willingness to communicate could be the main reason for the research results. During administering the research questionnaire, the students claimed that writing was an effective skill in order to improve their communicative skills. Therefore, it may be concluded that writing skill and willingness to communicate have a direct relationship with each other.
The findings of the present study are in line with MoradiKhazaei, MoinZadeh and Ketabi (2012) who investigated the effect of class size on the Iranian EFL learners' willingness to communicate among three different class sizes. The obtained results revealed that class size did have a significant effect on the participation of learners in class discussions and willingness to communicate. In another research, Valadi, Rezaee, and KoganiBaharvand (2015) were other researchers in the field who investigated whether WTC and language learners' oral proficiency were related in an Iranian context. The obtained results indicated that there was a strong correlation between the participants WTC level and their oral proficiency. In other words, those learners having a high level of WTC to open up a conversation are more competent in the speaking ability in the classroom.

The findings of the current study match Baghaei and Dourakhshan (2012) who attempted to explore the possible relationship between WTC and its components and success in foreign language learning. The obtained results showed that two out of the three subscales of WTC, namely, willingness to communicate in the school context and willingness to communicate with native speakers of English, were moderately correlated with success in learning English as foreign language as measured by $\mathrm{C}$-Test. The other subscale of willingness to communicate with nonnative speakers of English was not correlated with success in foreign language learning. 


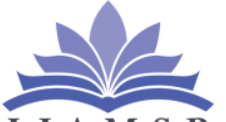

I J A M S R

International Journal of Advanced Multidisciplinary Scientific Research (IJAMSR) ISSN:2581-4281

The findings of this research also agree with Tousi and Khalaji (2014) who attempted to explore Iranian EFL learners' degree of willingness to communicate in English. It was found out at both tests; talking sessions were effective and the experimental group outperformed the control group. Based on the statistical procedures on the data, they were on safe grounds to claim that there was a statistically significant relationship between Iranian learners' WTC and their degree of learning English. Likewise, Bergil (2016) did a research in order to investigate the Turkish preparatory class students' WTC levels and the effects of individual differences on their WTC levels. The results showed that preparatory class students had mostly weak and adequate overall speaking skills which could be related with the activities the instructors and the curriculum included for the course contentment or the ability of instructors' material adaptation.

\section{Implications of the Study}

Several implications could be drawn from the results of this study. The findings of this research are important because they help language teachers and researchers in the field of TEFL to reveal the relationship between willingness to communicate and writing proficiency of the EFL learners in order to improve their learners' writing ability. Each stud could have a better understanding of his/her strengths and weaknesses in writing and would then be able to improve his/her writing ability. Nowadays, teaching writing is considered very important. The relationship between willingness to communicate and writing proficiency even the EFL learners may prove worthwhile to look into in order to improve the EFL learners' writing ability.

\section{Conclusion}

Overall, based on the results of the present research, it seems legitimate to claim that willingness to communicate plays a significant role in improving EFL learners' writing proficiency. This implies that EFL teachers need to explore the potentials of willingness to communicate in their classes by recognizing the factors contributing to and enhancing this important trait. As this research was limited to EFL learners at upperintermediate and advanced levels, it would seem advisable for teachers and researchers to conduct further research in this area focusing on a wider range of levels and extending the scope of the experiment by involving learners from various backgrounds and in different contexts. 


\section{International Journal of Advanced Multidisciplinary Scientific Research (IJAMSR) ISSN:2581-4281}

\section{References}

1) Ahmed Mahdi, D. (2014). Willingness to communicate in English: A casestudy of EFL Students at King Khalid University. English Language Teaching, 7(7), 58-71.

2) Al Asmari, A. R. (2013). Investigation of writing strategies, writing apprehension, and writing achievement among Saudi EFL-major students. International Education Studies, 6 (11), 62-83.

3) Alhaisoni, E. (2012). The effect of writing proficiency on writing planning strategy use: A case study of Saudi learners of English. International Journal of Linguistics, 4 (3),78-102.

4) Alsamadani, H. A. (2010). The relationship between Saudi EFL students' writing competence, L1 writing proficiency, and self-regulation. European Journal of Social Sciences, 16(1), 53-63.

5) Baghaei, P., \&Dourakhshan, A. (2012). The relationship between Willingness to Communicate and Success in Learning English as a Foreign Language. Elixir International Journal, 53 (1), 12160-12164.

6) Baghaei, P., \&Dourakhshan, A. (2012). The relationship between willingness to communicate and success in learning English as a foreign language. MJAL, 4 (2), 53-67.

7) Bergil, A. S. (2016). The influence of willingness to communicate on overall speaking skills among EFL learners. Procedia - Social and Behavioral Sciences 232 (1) 177-187.

8) Brown, H. D. (2007). Principles of language learning teaching (5th Ed.). United States of America: Pearson Education, Inc.

9) Cetinkaya, Y.B. (2005). Turkish college students' willingness to communicate in English as a foreign language. School of the Ohio State University, Ohio, USA.

10) Ghonsooly, B., \& Hosseini Fatemi, A., \&Khajavy, G. H. (2014). Examining the relationships between willingness to communicate in English, communication confidence, and classroom environment. International Journal of Research Studies in Educational Technology, 3(1), 63-71.

11) Hammad, E. A. (2013). Palestinian university students' problems with EFL essay writing in an instructional setting. Journal of Second and Multiple Language Acquisition - JSMULA, 2(1), 88-100.
12) Khabiri, M., \& Rouhani-Tonekboni, F. (2009). How to boost academic essay writing: A choice between process and product writing. Journal of Teaching English as a Foreign Language and Literature, 1(3), 53-74.

13) Khorasani, M., \&AminiHarsini, M. (2015). The relationship among willingness to communicate, topic, familiarity and Iranian intermediate EFL learners' writing ability. International Journal of Language Learning and Applied Linguistics World (IJLLALW), 8(1), 18696.

14) Kim, S.J. (2004). Exploring willingness to communicate (WTC) in English among Korean EFL (English as a Foreign Language) students in Korea: WTC as a predictor of success in second language acquisition. School of the Ohio State University, Ohio, USA.

15) Langan, J. (2005). College writing skills. Atlantic Cape Community College: McGraw Hill

16) Luchini, P. L. (2010). Evaluating the effectiveness of a complimentary approach to teaching writing skills. International Journal of Language Studies (IJLS), 4(3), 73-92.

17) MacIntyre, P. D. (2007). Willingness to communicate in the second language: Understanding the decision to speak as a volitional process. The Modern Language Journal, 91(4), 564-76.

18) MacIntyre, P. D., Clément, R., Dörnyei, Z., \& Noels, K. (1998). Conceptualizing willingness to communicate in a L2: A situational model of L2 confidence and affiliation. Modern Language Journal, 82(4), 545-62.

19) Mahmoodi, M.H., \&Moazzam, I. (2014). Willingness to communicate (WTC) and L2 achievement: The case of Arabic language learners. Procedia - Social and Behavioral Sciences, 98 (1), $1069-1076$

20) Merç, A. (2014). The relationship between WTC Level and LLS Use among Turkish EFL learners. Anadolu Journal of Educational Sciences International, 4(2), 58-81.

21) Moazzam, I. (2014). A comparison of willingness to communicate (WTC) between Iranian EFL and EAP learners. International Journal of Research Studies in Language Learning, 3(7), 57-72. 
https://doi.org/10.31426/ijamsr.2018.1.10.1018

22) MoradiKhazaei, Z., MoinZadeh, A., \&Ketabi, S. (2012). Willingness to communicate in Iranian EFL learners: The effect of class size. English Language Teaching, 5 (11), 181-188.

23) Peng, J. (2007). Willingness to communicate in an L2 and integrative motivation among college students in an intensive English language program in China. The University of Sydney, 2, 33-59.

24) Raime, A. (1985). What unskilled ESL students do as they write: A classroom study of composing. TESOL Quarterly, 19, 229-258.

25) Riasati, M. J. (2012). EFL learners' perception of factors influencing willingness to speak English in language classrooms: A qualitative study. World Applied Sciences Journal, 17(10), 1287- 1297.

26) Richards, J. C., \& Schmidt, R. (2010). Longman dictionary of language teaching and applied linguistics (4thEd.). London: Longman. 